\title{
Teknik dan Metode Penerjemahan Istilah Artistik Dalam manga Nodame Cantabile Volume 1- 25 Karya Tomoko Ninomiya
}

\author{
Ni Putu Eka Suwari Dewi ${ }^{1^{*}}$, Renny Anggraeny ${ }^{2}$ \\ ${ }^{[123]}$ Program Studi Sastra Jepang Fakultas Ilmu Budaya, Universitas Udayana \\ ${ }^{1}$ [echaelf95@gmail.com] ${ }^{2}$ [anggraeny0309@yahoo.co.jp] \\ *Corresponding Author
}

\begin{abstract}
Abstrak
Penelitian ini berjudul "Teknik dan Metode Penerjemahan Istilah Artistik dalam Manga Nodame Cantabile volume 1-25 karya Tomoko Ninomiya", penelitian ini menggunakan teknik penerjemahan Molina dan Albir (2002), metode penerjemahan Newmark (1988), dan teori komponen makna yang dikemukakan oleh Nida dan Taber (1969). Berdasarkan hasil analisis diperoleh 126 data istilah artistik. Menurut 18 teknik penerjemahan yang dikemukakan oleh Molina dan Albir (2002) ditemukan 12 teknik yang digunakan dalam menerjemahkan istilah artistik dalam manga Nodame Cantabile volume 1-25 karya Tomoko Ninomiya yaitu adaptasi, amplifikasi, peminjaman, deskripsi, kreasi diskursif, generalisasi, amplifikasi linguistik, kompresi linguistik, harfiah, kalke, padanan lazim dan transposisi, selanjutnya data dianalisis untuk menentukan metode penerjemahan yang digunakan. Metode penerjemahan yang digunakan dalam penelitian ini yakni metode penerjemahan harfiah dari Newmark (1988). Berdasarkan keseluruhan data, ditemukan 10 data yang mengalami pergeseran makna istilah artistik yang dianalisis dengan teori Nida dan Taber (1969).
\end{abstract}

Kata kunci : istilah artistik, teknik penerjemahan, metode penerjemahan, pergeseran makna

\begin{abstract}
This research, entitled "Translations technique and methods of artistic terms on manga Nodame Cantabile Volume 1-25 by Tomoko Ninomiya", used the theory of translation techniques by Molina and Albir (2002), theory of translation methodes by Newmark (1988) and componential analysis by Nida and Taber (1969). Based on analysis result, there are 126 data of artistic terms. According to 18 translation techniques by Molina and Albir, 12 techniques were used for translate artistic terms on manga Nodame Cantabile Volume 1-25 by Tomoko Ninomiya, namely adaptation, amplification, borrowing, description, discursive creatios, generalization, linguistics amplification, linguistics compression, literal translation, calque, established equivalent, and transpotition. The data was also analyzed to determine the method of translation. Translation method that was used in this research is literal translation by Newmark (1988). From 126 data, there are 10 data caused the shift of meaning of artistic terms that analyzed by the theory of Nida and Taber (1969).
\end{abstract}

Keywords : artistic terms, translation techniques, translation methodes, shift meaning

\section{Latar Belakang}

Penerjemahan adalah proses memindahkan pesan dengan padanan yang sealami mungkin dari bahasa sumber ke bahasa sasaran dengan memperhatikan gaya bahasanya. Dalam menerjemahkan terdapat istilah-istilah khusus yang 
terkadang tidak bisa diterjemahkan begitu saja, salah satunya istilah artistik. Menurut KBBI artistik sendiri memiliki arti mempunyai nilai seni, bersifat seni, mempunyai bakat dalam kesenian dan mempunyai rasa seni. Pengertian seni mencangkup segala kreasi manusia seperti puisi, drama, musik, tarian, seni pahat, ukir, bangunan, melukis dan masih banyak lagi. Penelitian ini memfokuskan pada seni musik dan bangunan sebagai ruang lingkup penelitian istilah artistik.

Manga Nodame Cantabile menceritakan hal-hal tentang musik klasik, teater, orkestra, dan sebagainya yang cocok dengan penelitian ini. Melalui penelitian ini diharapkan dapat dipahami tentang penerapan teknik dan metode penerjemahan dalam manga Nodame Cantabile karya Tomoko Ninomiya.

Kata atau ungkapan yang mengandung unsur budaya tidak mudah untuk diterjemahkan. Kata atau ungkapan dalam bahasa sumber akan kehilangan sebagian makna atau pesannya apabila diterjemahkan karena tidak adanya padanan yang tepat dalam budaya sasarannya (Hartono, 2003: 152). Pergeseran makna terjadi karena perbedaan sudut pandang budaya penutur bahasa yang berbeda-beda. Pergeseran di bidang makna ini pun mengakibatkan bahwa tidaklah selalu mungkin memindahkan makna yang terdapat di dalam teks secara tepat atau utuh (Simatupang, 1999:78). Oleh karenanya setelah menganalisis teknik dan metode penerjemahan, selanjutnya penulis tertarik untuk menganalisis komponen makna pada masing-masing $\mathrm{TSu}$ dan $\mathrm{TSa}$ berdasarkan komponen makna yang dikemukakan oleh Nida Taber (1969:77).

\section{Pokok Permasalahan}

Masalah yang terdapat di dalam penelitian ini dapat dirumuskan sebagai berikut:

a. Bagaimanakah teknik dan metode penerjemahan istilah artistik dalam manga Nodame Cantabile karya Tomoko Ninomiya?

b. Bagaimanakah pergeseran makna yang terjadi pada istilah artistik dalam manga Nodame Cantabile karya Tomoko Ninomiya?

\section{Tujuan Penelitian}

Tujuan penelitian dibagi menjadi dua, yaitu tujuan umum dan tujuan khusus. Secara umum tujuan penelitian ini untuk menambah wawasan para pembaca tentang bagaimana teknik dan metode penerjemahan dalam pengaplikasiannya pada karya sastra Jepang. Secara khusus tujuan penelitian ini adalah untuk mengetahui teknik dan metode penerjemahan serta pergeseran makna yang terjadi pada penerjemahan istilah artistik manga Nodame Cantabile Volume 1-25 karya Tomoko Ninomiya.

\section{Metode Penelitian}

Data pada penelitian ini dikumpulkan dengan menggunakan metode simak dan teknik catat. Pada tahapan analisis data menggunakan metode agih (distribusional). Metode agih yakni metode yang alat penentunya justru bagian dari bahasa yang bersangkutan itu sendiri (Sudaryanto, 1993:15). Teori yang digunakan untuk menganalisis teknik dan metode penerjemahan adalah teori teknik penerjemahan dari Molina dan Albir (2002) serta teori Metode penerjemahan dari Newmark (1988). Teori analisis 
komponen makna dari Nida dan Taber digunakan untuk menganalisis pergeseran makna istilah artistik pada manga Nodame Cantabile Volume 1-25 karya Tomoko Ninomiya.

\section{Hasil dan Pembahasan}

\subsection{Teknik Penerjemahan Istilah Artistik}

Dari 18 teknik penerjemahan yang dikemukakan oleh Molina dan Albir (2002), ditemukan 12 teknik penerjemahan yang digunakan dalam menerjemahkan istilah artistik dalam manga Nodame Cantabile karya Tomoko Ninomiya.

\subsubsection{Adaptasi}

(1) TSu:だって凱旋門やエッフェル搭 にも行きたいし

(Nodame Cantabile Volume 10, 2004 :45) TSa: Habis, nodame juga ingin lihat Arch

De Triomphe dan menara Eiffel

(Nodame Cantabile Volume 10, 2006 :45)

Pada data (1) terdapat kata gaisenmon yang berarti gerbang kemenangan, namun diterjemahkan menjadi Arch De Triomphe dalam BSa yang merupakan salah satu nama bangunan di kota Paris, Prancis. Arch De Triomphe merupakan bahasa Prancis yang memiliki arti lengkungan kemenangan, namun dalam BSa istilah gaisenmon apabila diterjemahkan dalam Nelson (2011:193) secara harfiah memiliki arti gerbang kemenangan. Setelah menelaah kedua arti dalam bahasa Indonesia maupun bahasa Prancis istilah gaisenmon ini sama - sama memiliki makna gerbang atau bangunan yang merupakan simbol kemenangan.

\subsubsection{Amplifikasi}

(2) TSu:「J. Jフックス」著の「グラ デウス. アド. バルナッスム」

「対位法」

(Nodame Cantabile Volume 3, 2002 : 22)

TSa : Tulisan "J.J. Fuchs" tentang "Gradousse Ad Parnassum" untuk belajar "Counterpoint".

(Nodame Cantabile Volume 3, 2005 : 22)

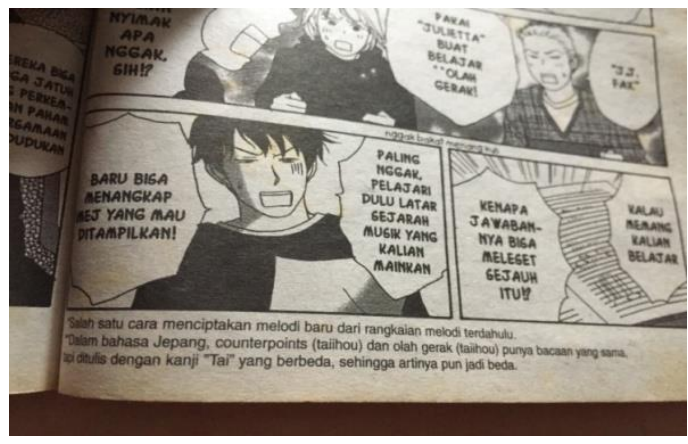

Gambar 1 catatan kaki counterpoint

Salah satu jenis yang termasuk ke dalam teknik amplifikasi adalah catatan kaki. Keraf (1994:193) menjelaskan bahwa catatan kaki merupakan daftar keterangan khusus yang ditulis di bagian bawah karya. Catatan kaki bisa digunakan untuk memberikan keterangan atau menjelaskan sumber kutipan. Kata taiihou diterjemahkan dengan istilah counterpoint dengan menambahkan penjelasan pada bagian bawah manga sebagai "salah satu cara menciptakan melodi baru dari rangkaian melodi terdahulu". Penambahan arti counterpoint pada bagian bawah manga tentunya akan sangat membantu pembaca yang tidak memahami istilah istilah musik dan menambah wawasan bagi mereka yang memiliki ketertarikan pada bidang ini. 


\subsubsection{Borrowing}

(3) TSu:だってボク演奏だけじやなく て作曲だってできるようになりた い。カデンツアだって自分で作り たい。

(Nodame Cantabile Volume 12, 2005 :166)

TSa: Habis kau kan tidak hanya ingin jadi performer saja, aku juga ingin bisa berkarya sebagai seorang komposer. Aku juga ingin menulis Cadenza untuk kumainkan sendiri. (Nodame Cantabile Volume 12, 2006 :166) Data (3) mengggunakan peminjaman sebagai teknik penerjemahan. Kata cadenza dipinjam begitu saja tanpa adanya perubahan struktur gramatikal yang mencolok. Cadenza sendiri berarti bagian yang cukup panjang untuk dimainkan oleh pemain solo dalam sebuah konser atau orkestra yang dimainkan mendekati akhir. Situasi pada data (3) menggambarkan bahwa penutur ingin menulis bagian cadenza-nya sendiri untuk menunjukkan keahliannya.

\subsubsection{Deskripsi}

(4) TSu: オルセ一美術館

(Nodame Cantabile Volume 12, 2005 :80)

TSa: Museum Louvre adalah salah satu museum terbesar, museum seni yang paling banyak dikunjungi dan sebuah monumen bersejarah di dunia. Museum Louvre terletak di Rive Droite Seine, Arondisemen pertama di Paris, Prancis.

(Nodame Cantabile Volume 12, 2006 :80)

Sesuai dengan arti istilah artistik, bahwa nama bangunan juga termasuk kategori ini sebagaimana yang tertera seperti data (4). Terjemahan Museum Louvre pada data (4) dideskripsikan sebagai salah satu bangunan museum yang terkenal di Prancis. Di dalam TSu hanya ditulis istilah Museum Louvre, namun dalam TSa penerjemah mendeskripsikan tentang hal sebenarnya Museum Louvre yang dimaksud untuk memperjelas maksud dari TSu.

\subsubsection{Kreasi Diskursif}

(5) TSu:わたしも....むこう行ったら室

内楽 もやるんだ!

(Nodame Cantabile Volume 10, 2004 : 7) TSa : Aku juga... nanti setelah kembali ke sana, aku akan bergabung dengan Chamber musik.

(Nodame Cantabile Volume 10, 2006 : 7)

Data (5) menitikberatkan shitsunaigaku sebagai istilah yang diteliti. Shitsunaigaku memiliki arti musik kamar (Nelson, 2011:319). Namun, dalam BSa diterjemahkan menjadi Chamber Musik yang artinya sebuah kelompok musik atau musisi yang dapat melakukan pertunjukan dengan mudah di gedung konser yang kecil atau rumah pribadi. Kedua terjemahan sangatlah tidak berkaitan, musik dalam kamar dan chamber musik ini memiliki konteks yang berbeda, yangmana situasi penutur pada data (5), si tokoh suatu saat nanti mungkin akan tergabung dengan orkestra yang lebih kecil bukan orkestra yang besar seperti saat ini, sedangkan musik kamar ini musik yang dimainkan dalam kamar sangatlah keluar dari konteks yang dimaksud. 


\subsubsection{Generalisasi}

(6) TSu:チェロにコンバスもっと音程 気をつけて！

(Nodame Cantabile Volume 3, 2002: 47 )

TSa: Cello dan kontra bass perhatikan interval kalian!

(Nodame Cantabile Volume 3, 2005: 47 )

Pada data (6) BSu ontei diterjemahkan menjadi interval dalam BSa. Apabila diterjemahkan secara harfiah interval merupakan 'perbedaan tinggi antara dua nada berdasarkan perbandingan frekuensinya'. Namun, penerjemah memilih menggunakan interval sebagai BSa karena istilah ini merupakan istilah yang secara umum digunakan oleh pelaku seni musik dalam berkomunikasi tanpa harus menggunakan kata-kata panjang yang kurang efektif.

\subsubsection{Amplifikasi Linguistik}

(7)

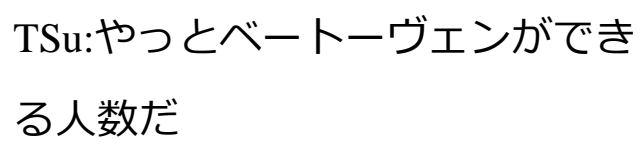

( Nodame Cantabile Volume 7, 2003 : 21)

TSa: Akhirnya jumlah yang terkumpul cukup untuk memainkan bahkan karya-karya simfoni Bethoven sekalipun

( Nodame Cantabile Volume 7, 2006 : 21)

Teknik amplifikasi linguistik diterapkan untuk memperjelas maksud ujaran penutur dengan menambahkan beberapa kata sesuai dengan konteks. Kata Beethoven pada TSu ditambahkan menjadi 'karya-karya simfoni Bethoven' dalam TSa. Hal ini diterapkan untuk memperjelas maksud yang ingin disampaikan penulis dengan menambahkan kata yang sesuai dengan konteks ujaran.

\subsubsection{Kompresi Linguistik}

(8) TSu: これがオケピか！！

( Nodame Cantabile Volume 25, 2010 :74) TSa: Jadi ini ochepi nya?

( Nodame Cantabile Volume 25, 2011 :74)

Data (8) termasuk ke dalam teknik Kompresi Linguistik. Istilah ochepi merupakan singkatan dari Orchestra pit yang memiliki arti tempat para pemain orkestra yang terletak di antara panggung dan kursi penonton, sengaja dibuat setingkat lebih tinggi dari kursi penonton. Kata orkestra pada BSu disingkat menjadi oke saja. Istilah okepi ini memperlihatkan adanya pengurangan atau reduction dalam $\mathrm{TSu}$ maupun TSa, sehingga teknik kompresi linguistik dipilih untuk diterapkan pada data (8)

\subsubsection{Penerjemahan Harfiah}

(9) TSu:打楽器奏者がひとり足りてな

いから最後は僕がゴングにミュー

トをかけなければ

(Nodame Cantabile Volume 14, 2006: 310)

TSa: Karena pemain perkusinya kurang satu, aku yang harus mute dengan gong penutup sebagai bagian terakhir (Nodame Cantabile Volume 14, 2006: 310)

Data (9) merupakan salah satu contoh penerapan Teknik Penerjemahan Harfiah. Daggaki memiliki arti perkusi atau jenis alat musik yang dipukul, sedangkan sousha memiliki arti pemain instrumen suatu alat musik. Berdasarkan data (9) penerjemahan dilakukan dengan menerjemahkan kata per kata pada BSa sehingga tidak mengalami suatu perubahan apapun.

\subsubsection{Kalke}

(10) TSu: 武満徹 


\section{〈違い呼び声の彼方へ!〉}

(Nodame Cantabile Volume 12, 2005 : 52)

TSa: Toru Takemitsu (A Distant Cry From Far Away)

(Nodame Cantabile Volume 12, 2006 : 52)

Data (10) diterjemahkan secara literal namun terjemahan yang dihasilkan memiliki struktur kalimat yang berbeda. Apabila penerjemah menggunakan teknik penerjemahan literal maka terjemahan yang dihasilkan menjadi Takemitsu Tooru dibanding Tooru Takemitsu sehingga teknik kalke merupakan teknik yang cocok untuk diterapkan pada data (10).

\subsubsection{Padanan Lazim}

(11) TSu: 楽譜みてねーじやね一か！！

(Nodame Cantabile Volume 1, $2002: 74$ )

TSa :Partiturnya sama sekali nggak dilirik!

(Nodame Cantabile Volume 1, 2005 : 74)

Pada data (11) TSu gafuku diterjemahkan menjadi 'partitur' dalam BSa yang merupakan istilah yang sudah lazim dan diketahui oleh masyarakat luas. Partitur sendiri merupakan salah satu istilah di bidang musik yang memiliki arti tulisan musik (bagian musik) dari setiap jenis alat musik serta suara yang turut ambil bagian dalam sebuah komposisi (Kodijat, 2004: 73). Jika diterjemahkan secara harfiah gakufu ini memiliki arti kertas/lembaran/buku/notasi musik (Nelson, 2011: 508). Istilah ini merupakan istilah yang sudah diketahui luas oleh masyarakat umum bukan hanya mereka yang mengerti ataupun belajar musik saja, sehingga teknik padanan lazim sangat cocok diterapkan pada data (11).

\subsubsection{Transposisi}

(12) TSu: フルートの工キストラさん ?

(Nodame Cantabile Volume 13, 2005 :121)

TSa: Pemain untuk ekstra flute?

(Nodame Cantabile Volume 13, 2006 :121)

Pengaruh teknik transposisi dapat dilihat pada perubahan kelas kata pada data (12). Kata san yang merupakan suffix (akhiran) pada ujaran bahasa Jepang diterjemahkan menjadi 'pemain' yang merupakan nomina pada BSa. Dengan adanya terjemahan 'pemain' dalam BSa ini membantu para pembaca yang tidak mengerti bahasa Jepang untuk lebih memahami makna kalimat pada data (12) daripada tetap mempertahankan struktur gramatikal BSu.

\subsection{Metode Penerjemahan}

Metode penerjemahan merupakan cara sebuah proses penerjemahan dilakukan sesuai dengan tujuan penerjemah. Berdasarkan hasil analisis terhadap teknikteknik penerjemahan, dapat diketahui bahwa dari dua belas teknik penerjemahan yang teridentifikasi, dua teknik berorientasi pada BSu dan sepuluh teknik berorientasi pada BSa. Sesuai dengan metode penerjemahan yang dikemukakan oleh Newmark, penelitian ini menggunakan metode penerjemahan harfiah. Metode ini sangat cocok diterapkan, mengingat sebagian besar teknik yang diterapkan dalam data - data yang telah dikumpulkan merupakan teknik peminjaman. Data - data yang diterjemahkan sebagian besar dipinjam ataupun diterjemahkan sesuai dengan kamus tanpa banyak perubahan gramatikal dan tanpa mengurangi makna yang ingin disampaikan oleh penulis. 


\subsection{Pergeseran Makna Teknik Penerjemahan}

Dari keseluruhan 126 data, terdapat 10 data yang termasuk kedalam enam teknik penerjemahan yang mengalami pergeseran makna dari BSu kedalam BSa. Berikut beberapa data yang mengalami pergeseran makna karena penerjemah ingin tetap mempertahankan budaya asli yang terkandung dalam Bsu.

\subsubsection{Adaptasi}

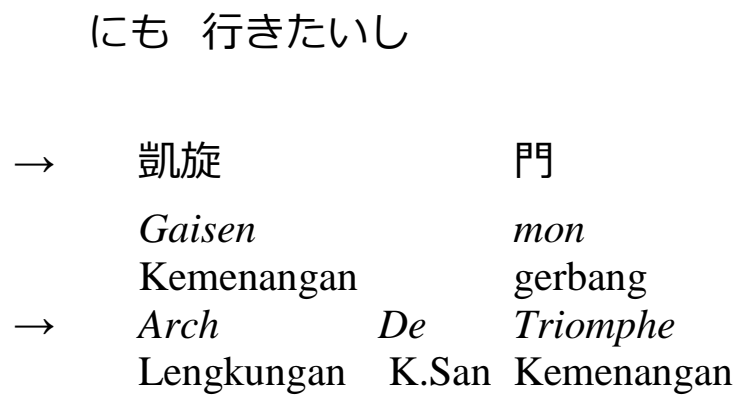

Tabel 1 Analisis komponen makna gaisenmon dan Arch De Triomphe

\begin{tabular}{lcc}
$\begin{array}{l}\text { Komponen } \\
\text { makna }\end{array}$ & Gaisenmon & $\begin{array}{c}\text { Arc De } \\
\text { Triomphe }\end{array}$ \\
\hline Bangunan & + & + \\
$\begin{array}{l}\text { Berbentuk } \\
\text { lengkungan }\end{array}$ & - & + \\
$\begin{array}{l}\text { Mengandung } \\
\text { arti } \\
\text { kemenangan }\end{array}$ & + & + \\
\hline
\end{tabular}

Berdasarkan analisis komponen makna, "gaisenmon" dan "Arch De Triomphe" memiliki makna yang sama yakni suatu benda yang berdiri kokoh yang memiliki arti kemenangan didalamnya. Menurut Kamus Besar Bahasa Indonesia (KBBI) gerbang memiliki arti 'pintu masuk', sedangkan lengkungan memiliki arti 'bidang atau sisi yang melengkung'. Dari penjelasan tersebut kata gerbang dan lengkungan mengalami pergeseran makna, tetapi tetap mempertahankan makna sesungguhnya yaitu sebuah bangunan yang berdiri kokoh dan melambangkan suatu kemenangan.

\subsubsection{Generalisasi}
(14) TSu： なんや コラ..... 総譜 ? Nanya kora..... soufu Apa ini skor penuh

TSa : apa ini... Kompilasi partitur?

Tabel 2 Analisis komponen makna soufu dan Akor

\begin{tabular}{lcc}
\hline $\begin{array}{l}\text { Komponen } \\
\text { makna }\end{array}$ & Soufu & $\begin{array}{c}\text { Kompilasi } \\
\text { partitur }\end{array}$ \\
\hline $\begin{array}{l}\text { Kumpulan } \\
\text { kertas }\end{array}$ & + & + \\
$\begin{array}{l}\text { Semua } \\
\text { lembar musik }\end{array}$ & + & \pm \\
$\begin{array}{l}\text { Tersusun } \\
\text { secara rapi }\end{array}$ & \pm & +
\end{tabular}

Berdasarkan penjelasan data (14) soufu dan "kompilasi partitur" memiliki makna yang berdekatan yaitu "kumpulan kertas musik yang digunakan konduktor dalam sebuah orkestra'. Partitur-partitur dari tiap komposisi dikumpulkan dan disusun secara teratur sehingga ketika orkestra dimulai tidak ada partitur yang tercecer. Dalam KBBI 'kompilasi' memiliki makna kumpulan yang tersusun secara teratur, sedangkan "partitur" memiliki arti bentuk tulisan atau tercetak pada komposisi musik. Pergeseran penerjemahan terjadi yang mana soufu mencangkup semua atau keseluruhan partitur, namun kompilasi hanya terbatas terhadap kumpulan saja tanpa adanya keterangan apakah keseluruhan partitur digunakan atau hanya beberapa saja. 
5.3.3 Amplifikasi Linguistik

(15) TSu:指揮科の早川<ん留学するん だってー

$\rightarrow$ 指揮

科

Shiki

$k a$

Pengarah

fakultas

$\rightarrow \quad$ Pengarah musik dan asembel

Tabel 3 Analisis komponen makna istilah Shikika dan pengarah musik dan asembel

\begin{tabular}{lcc}
\hline $\begin{array}{l}\text { Komponen } \\
\text { makna }\end{array}$ & Shikika & $\begin{array}{c}\text { Pengarah } \\
\text { musik dan } \\
\text { asembel }\end{array}$ \\
\hline $\begin{array}{l}\text { Istilah musik } \\
\text { Kelompok }\end{array}$ & + & + \\
musik & - & + \\
Tempat & + & - \\
menimba & & \\
ilmu & & \\
conducting & & \\
\hline
\end{tabular}

Berdasarkan analisis komponen makna pada data (15) "shikika" dan "pengarah musik \& asembel' sedikit melenceng dari makna yang ingin disampaikan dalam BSu yang sebenarnya. Shikika memiliki arti fakultas pengarahan yang dalam bahasa Inggris disebut dengan conducting. Di sisi lain TSa pengarah musik dan asembel memiliki arti orang yang mengarahkan musik atau disebut konduktor dan kelompok musik yang bermain secara tetap (asembel). TSa pengarah musik dan asembel tidak mencantumkan tempat pembelajaran seperti yang diungkapkan dalam TSu, namun menambahkan kata asembel yang tidak berkaitan dalam hasil terjemahan sehingga sedikit mengalami pergeseran makna dari $\mathrm{TSu}$ yang ingin disampaikan penulis.

\subsubsection{Transposisi}

(16) TSu: セカンドクラリネット音 污

え!

$\rightarrow$ 污え

Kitane

kotor

$\rightarrow \quad$ Distorsi

Tabel 4 Analisis komponen makna Kitane dan distorsi

\begin{tabular}{lcc}
\hline $\begin{array}{l}\text { Komponen } \\
\text { makna }\end{array}$ & Kitane & Distorsi \\
\hline Istilah musik & - & + \\
Kelompok kata & + & - \\
sifat & & \\
$\begin{array}{l}\text { Memiliki } \\
\text { makna }\end{array}$ & - & + \\
menyimpang & & \\
\hline \multicolumn{1}{c}{ Berdasarkan analisis data (16) } & istilah
\end{tabular}
kitane dan distorsi mengalami pergeseran makna yang dapat dilihat dari kelas kata kedua istilah tersebut. Kitane yang berarti 'kotor' merupakan kelas kata adjektiva sedangkan "distorsi" yang memiliki arti menyimpang atau penyimpangan dalam KBBI merupakan kelas kata nomina, sehingga data (16) merupakan salah satu data yang mengalami pergeseran makna.

\subsubsection{Deskripsi}

(17) TSu:オペラとは音楽と絵画美術と演 劇の総合芸術

$\begin{array}{lll}\rightarrow & \text { 絵画 } & \text { 美術 } \\ & \text { Kaiga } & \text { bijutsu } \\ & \text { Gambar } & \text { seni } \\ \rightarrow \quad & \text { Visual } & \end{array}$


Tabel 5 Analisis komponen makna kaiga bijutsu dan visual

\begin{tabular}{lcc}
\hline $\begin{array}{l}\text { Komponen } \\
\text { makna }\end{array}$ & $\begin{array}{c}\text { Kaiga } \\
\text { bijutsu }\end{array}$ & Visual \\
\hline $\begin{array}{l}\text { Berhubungan } \\
\text { dengan seni }\end{array}$ & + & + \\
$\begin{array}{l}\text { Perlu alat tulis } \\
\begin{array}{l}\text { Dilihat oleh } \\
\text { mata }\end{array}\end{array}$ & + & - \\
\end{tabular}

Berdasarkan pemaparan analisis
komponen makna data (17) dapat
disimpulan bahwa kedua istilah yang
dijadikan objek penelitian mengalami
pergeseran makna. Kaiga dalam kamus
(Nelson: 2011) diterjemahkan menjadi
'gambar' yang berarti 'tiruan barang yang
dibuat dengan coretan pensil pada kertas'
(KBBI), bijutsu yang berarti 'seni',
sedangkan visual memiliki arti 'dapat
dilihat dengan indera penglihatan'.
Ketidaksesuaian makna terlihat dari makna
kaiga bijutsu yang seharusnya
diiterjemahkan menjadi 'seni menggambar'
daripada "visual" saja. Dari porsi kalimat
istilah kaiga bijutsu terdiri dari dua kata
namun terjemahan BSa hanya terdiri dari
satu kata saja.

\subsubsection{Kreasi Diskursif}

(18) TSu: 選抜学生の協奏曲コンサート

$\begin{array}{lll}\rightarrow & \text { 協奏曲 } & \text { コンサート } \\ & \text { Kyousoukyoku } & \text { konsaato } \\ & \text { Concerto } & \text { kolaborasi } \\ \rightarrow \quad & \text { Konser kolaborasi } & \end{array}$

Tabel 6 Analisis komponen makna kyosoukyoku konsaato dan konser kolaborasi

\begin{tabular}{lcc}
\hline $\begin{array}{l}\text { Komponen } \\
\text { makna }\end{array}$ & $\begin{array}{l}\text { Kyousoukyoku } \\
\text { konsaato }\end{array}$ & $\begin{array}{c}\text { Konser } \\
\text { kolabor } \\
\text { asi }\end{array}$ \\
\hline $\begin{array}{l}\text { Berhubungan } \\
\text { dengan }\end{array}$ & + & + \\
konser \\
$\begin{array}{l}\text { Dilakukan } \\
\text { dengan } \\
\text { berkolaborasi }\end{array}$ & - & + \\
$\begin{array}{l}\text { Adanya } \\
\text { pemain } \\
\text { musik lain }\end{array}$ & + & + \\
\hline
\end{tabular}

Berdasarkan analisis komponen makna, data (18) yang menghasilkan terjemahan kyosoukyoku konsaato dan "konser kolaborasi" memiliki makna yang sama dengan komponen makna pertama yaitu berhubungan dengan konser. Pembedanya terletak pada komponen makna kedua yang mana kyosoukyoku konsaato tidak dilakukan dengan berkolaborasi, sedangkan konser kolaborasi sudah pasti dilakukan dengan bersama-sama. Kyosoukyoku memiliki arti 'concerto' (Nelson: 2011) yang dalam bahasa Indonesia ialah komposisi musik yang dimainkan oleh biola, piano, dsb bersama orkestra (KBBI) dan konsaato yang memiliki arti 'konser'. Hasil terjemahan kolaborasi pada TSa sama sekali tidak berhubungan dengan kata kyosoukyoku maupun konsaato sehingga menimbulkan pergeseran makna antara $\mathrm{TSu}$ kyosoukyoku konsaato dan TSa "konser kolaborasi".

\section{Simpulan}

Berdasarkan 18 teknik penerjemahan yang dikemukakan oleh Molina dan Albir 
terdapat 12 teknik yang teridentifikasi yaitu adaptasi, amplifikasi, peminjaman, deskripsi, kreasi diskursif, generalisasi, amplifikasi linguistik, kompresi linguistik, harfiah, kalke, padanan lazim dan transposisi. Dari keseluruhan teknik penerjemahan, teknik peminjaman merupakan teknik yang paling banyak diaplikasikan. Adapun metode penerjemahan yang digunakan yakni metode penerjemahan harfiah, metode ini sangat cocok diterapkan mengingat sebagian besar teknik yang diterapkan dalam data - data yang telah dikumpulkan merupakan teknik peminjaman. Pergeseran makna teridentifikasi karena tidak adanya padanan yang sesuai dalam BSa, sehingga kata ataupun istilah dalam $\mathrm{BSu}$ diterjemahkan tanpa mengindahkan struktur gramatikal maupun kaitan budaya yang terkandung didalamnya.

\section{Daftar Pustaka}

Hartono. 2003. Belajar Menerjemahkan, Teori, dan Praktek. Malang.: UMM Press.

Keraf, Gorys. 1994. KOMPOSISI. Ende : Nusa Indah.

Kodijat, Latifah. 2004. Tangganada dan Trinada. Jakarta: Djambatan

Newmark, Peter. 1988. A Text Book of Translation. Oxford :Pergamon Press.

Nida, E.A. \& Taber. 1969. The Theory and Practice of Translation. Leiden: E.J.Brill

Simatupang, Mauris. 1999. Pengantar Teori Terjemahan. Jakarta: Depdiknas

Sudaryanto. 1993. Metode dan Aneka Teknik Analisis Bahasa: Pengantar Penelitian Wahana Kebudayaan Secara
Linguistis. Yogyakarta: Duta Wacana University Press.

\section{Daftar Kamus}

Kamus Besar Bahasa Indonesia. [Online]. Tersedia di http://kbbi.kemdikbud.go.id/ diakses pada 09 Desember 2017

Nelson, Andrew Nathaniel. 2011. KAMUS KANJI MODERN JEPANG INDONESIA. Jakarta: Kesaint Blanc

\section{Daftar Unduhan}

Molina L dan Albir, A.H. 2002.Translation Technique Revisited: A Dynamic and Functionalist Approach. Meta, Vol. XL VII, No.4 